\title{
Abnormal gas pattern under diaphragm
}

\author{
Devasmitha Venkataraman, Rachael Harrison, Stephen Warriner
}

Paediatrics Department, Portsmouth Hospitals NHS Trust, Portsmouth, UK

Correspondence to Dr Devasmitha Venkataraman,dr_devasmitha@yahoo.co.uk

\section{DESCRIPTION}

A 3-year-old boy presented with a week's history of fever, cough and mild shortness of breath, with no history of previous recurring chest or abdominal symptoms. His chest examination demonstrated basal crepts, and his abdominal examination was normal. Chest radiograph showed generalised inflammatory changes in lung fields and a radiolucent shadow under the right diaphragm with some haustral marking suggestive of interposition of colon between the diaphragm and liver (figure 1). This x-ray finding is called Chilaiditi's sign.

Chilaiditi's sign is a condition characterised by interposition of the small or large bowel between the liver and the right hemidiaphragm. Chilaiditi's sign is a radiographic term that becomes known as Chilaiditi syndrome when symptoms are present. ${ }^{1}$ It is a relatively rare condition in adults and children; and its prevalence in the general population ranges from $0.025 \%$ to $0.28 \% .^{2}$ Chilaiditi's sign is generally asymptomatic and identified as an incidental radiographic finding. Occasionally patients with Chilaiditi's sign have associated symptoms (abdominal

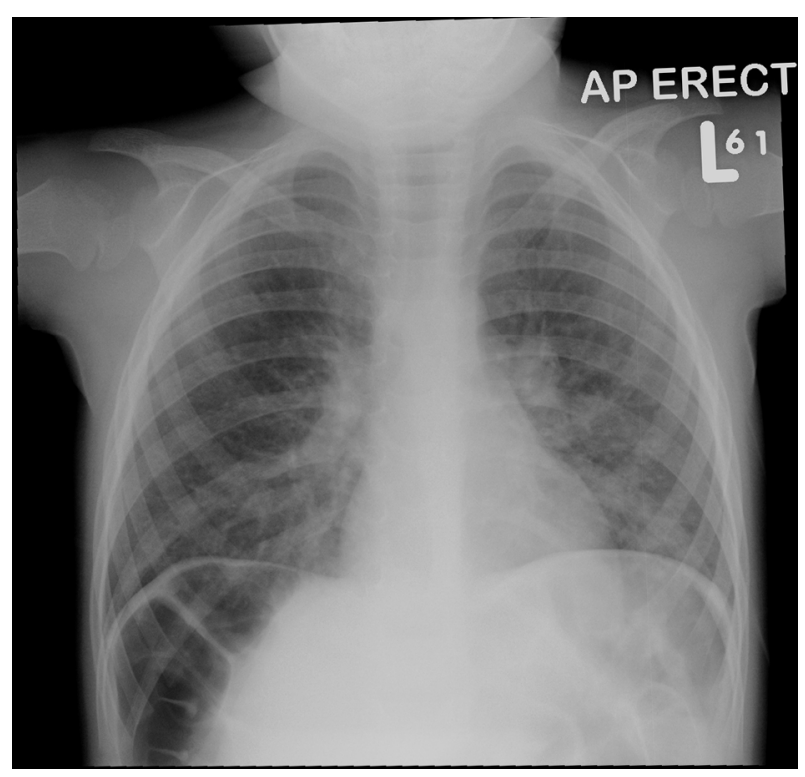

Figure 1 Chilaiditi's sign: gas under right diaphragm showing haustral markings (colon interposed between liver and diaphragm). pain, constipation, bowel obstruction), which respond to conservative therapy including nasogastric decompression, enemas and fluids. ${ }^{12}$

Chilaiditi's sign should be considered in the differential diagnosis of gas under right diaphragm along with other serious abnormalities including pneumoperitoneum, subphrenic abcesses, diaphragmatic hernias and retroperitineal masses, especially in cases of acute abdomen. Though haustral markings are diagnostic of colonic interposition, ${ }^{3}$ further imaging (ultrasound, CT scan) may be needed, if plain films are not conclusive of Chiladiti's syndrome in acute abdomen. Awareness of this condition could help reduce unnecessary exploratory laparotomies for misdiagnosed pneumo-peritoneum.

\section{Learning points}

- Chilaiditi's sign (interposition of small or large bowel between liver and diaphragm) presents as gas under right diaphragm on x-ray. This condition is usually asymptomatic. Presence of haustral markings help diagnose this condition.

- Chilaitditi's sign is an incidental finding on x-ray done for other clinical indications, and is very rare in children and adults. The presence of symptoms along with $x$-ray changes is designated Chilaiditi syndrome.

- Chilaiditi's sign could be mistaken for a more serious entity (pneumoperitoneum, subphrenic abcess or diaphragmatic hernia), especially in cases of acute abdomen, and further imaging should be sought (ultrasound scanning, CT scanning) to differentiate the causes.

\section{Competing interests None.}

Patient consent Obtained.

\section{REFERENCES}

1. Saber AA, Boros MJ. Chilaiditi's syndrome: what should every surgeon know? Am Surg 2005;71:261-3.

2. Risaliti A, De Anna D, Terrosu G, et al. Chilaiditi's syndrome as a surgical and nonsurgical problem. Surg Gynecol Obstet 1993;176:55-8.

3. Plorde JJ, Raker EJ. Transverse colon volvulus and associated Chilaiditi's syndrome: case report and literature review. Am J Gastroenterol 1996;91:2613-6. 


\section{BMJ Case Reports}

This pdf has been created automatically from the final edited text and images.

Copyright 2012 BMJ Publishing Group. All rights reserved. For permission to reuse any of this content visit http://group.bmj.com/group/rights-licensing/permissions.

BMJ Case Report Fellows may re-use this article for personal use and teaching without any further permission.

Please cite this article as follows (you will need to access the article online to obtain the date of publication).

Venkataraman D, Harrison R, Warriner S. Abnormal gas pattern under diaphragm. BMJ Case Reports 2012;10.1136/bcr.08.2011.4650, Published XXX

Become a Fellow of BMJ Case Reports today and you can:

- Submit as many cases as you like

- Enjoy fast sympathetic peer review and rapid publication of accepted articles

- Access all the published articles

- Re-use any of the published material for personal use and teaching without further permission

For information on Institutional Fellowships contact consortiasales@bmjgroup.com

Visit casereports.bmj.com for more articles like this and to become a Fellow

Keep up to date with all published cases by signing up for an alert (all we need is your email address) http://casereports.bmj.com/cgi/alerts/etoc 